\title{
PENGARUH PELATIHAN TERHADAP KOMPETENSI PENGURUS KOPERASI DI JAWA TIMUR DENGAN E-LEARNING SIJAWARA SEBAGAI VARIABEL INTERVENING
}

\author{
TIARA DINAR AULIA \\ UPT Pelatihan Koperasi dan UKM Provinsi Jawa Timur \\ Email : tiaradinaraulia.wi@gmail.com
}

\begin{abstract}
ABSTRAK
Penelitian ini bertujuan untuk menganalisis Pengaruh Pelatihan terhadap Kompetensi Pengurus Koperasi dengan Pemanfaatan E-Learning SIJAWARA sebagai Variabel Intervening di UPT Pelatihan Koperasi dan UKM Provinsi Jawa Timur, Populasi dalam penelitian adalah pengurus koperasi yang pernah mengikuti pelatihan dengan metode tatap muka dan pelatihan yang memanfaatan E-Learning SIJAWARA. Pengambilan sampel menggunakan metode sensus sampling yaitu semua populasi dijadikan sampel penelitian. Teknik pengambilan data menggunakan kuisioner dengan skala Likert 1 (satu) sampai 4 (empat). Pengolahan data menggunakan program SPSS versi 24 dengan pendekatan analisa kuantitatif deskriptif dan analisis kuantitatif inferensial. Hasil analisis data menunjukkan bahwa Pelatihan yang dilaksanakan UPT Pelatihan Koperasi dan UKM Provinsi Jawa Timur, Pemanfaatan ELearning SIJAWARA, dan Kompetensi Pengurus Koperasi yaitu pelatihan berpengaruh signifikan terhadap kompetensi pengurus koperasi, demikian juga bahwa Pemanfaatan $E$ Learning SIJAWARA dapat berfungsi sebagai variabel intervening antara variabel pelatihan dan variabel kompetensi pengurus koperasi di UPT Pelatihan Koperasi dan UKM Provinsi Jawa Timur.
\end{abstract}

Kata Kunci : SIJAWARA, Kinerja Pengurus Koperasi, Pelatihan Koperasi

\section{ABSTRACT}

This study aims to analyze the Effect of Training on Cooperative Management Competence by Utilizing SIJAWARA E-Learning as an Intervening Variable at the East Java Province Cooperatives and SMEs Training Unit. Learning SIJAWARA. Sampling using the census sampling method, that is, all populations are used as research samples. The data collection technique used a questionnaire with a Likert scale of 1 (one) to 4 (four). Data processing using SPSS version 24 program with descriptive quantitative analysis approach and inferential quantitative analysis. The results of data analysis show that the training carried out by the East Java Province Cooperative and SME Training UPT, SIJAWARA E-Learning Utilization, and Cooperative Management Competence, namely training has a significant effect on the competence of cooperative management, as well as that SIJAWARA E-Learning Utilization can function as an intervening variable between variable of training and variable of competence of cooperative management in UPT Cooperative and UKM Training East Java Province.

Keywords: SIJAWARA, Cooperative Management Performance, Cooperative Training

\section{PENDAHULUAN}

Koperasi merupakan salah satu lembaga keuangan tertua di Indonesia yang muncul sejak zaman penjajahan Belanda. Dibanding lembaga atau badan usaha lainnya, landasan kope-rasi memang berbeda. Kekeluargaan serta gotong royong merupakan prinsip utama lembaga keuangan ini (Ramadhani, 2020).

Menurut Subari (dalam Lipi, 2021) Mengatakan, sebagai wadah atau usaha yang memiliki peranan yang penting danstrategis bagi perekonomian Indonesia, koperasi harus mampu untuk membangun dan mengembangkan usaha bersama dengan orang-orang yang memiliki kemampuan baik secara ekonomi maupun pendidikan dengan daya saing tinggi serta 
mengambil peranan yang signifikan sehingga terbentuk koperasi di berbagaidaerah untuk dapat melakukan pelayanan dan berkontribusi dalam kesejahteraanmasyarakat.

Namun pada kenyataanya, masalah yang timbul pada pertumbuhan koperasi adanya peningkatan kuantitatif koperasi yang tidak diimbangi dengan kualitas yang baik (Asgar \& Rahayu, 2014). Kepala Dinkop dan Usaha Mikro Kota Malang Tri Widyani Pengestuti mengatakan bahwa "meski digadang-gadang sebagai soko guru ekonomi kerakyatan, keberadaan koperasi masih memprihatinkan. Misalnya di Kota Malang, jumlah koperasi didominasi oleh koperasi yang kondisinya tidak sehat (Malangtimes, 2019).

Beberapa survey awal dengan beberapa referensi menunjukkan bahwa hasil penelitian menunjukkan Koperasi mengalami perkembangan yang signifikan bila dilihat dari 5 (lima) indikator yaitu jumlah pertumbuhan koperasi, jumlah anggota yang aktif, penyerapan tenaga kerja, modal sendiri, serta indikator volume usaha semuanya mengalami peningkatan (Retnowati, 2010). Dan ada 3 (tiga) faktor yang membuat koperasi dapat bertahan dan berkembang, yaitu visi koperasi, kapasitas, jaringan kerja dan kompetensi sumberdaya. Dan perkembangan tersebut tidak lepas dari Kompetensi Pengurus Koperasi itu sendiri dalam mengelola manajemen.

Jawa Timur merupakan provinsi dengan jumlah koperasi yang terbanyak di Indonesia. Pada tahun 2019, terdapat 22.099 koperasi aktif di Jawa Timur atau 17,68 persen dari total koperasi di Indonesia. Pola pembelajaran konvensional yang dilaksanakan oleh UPT Pelatihan Koperasi dan UKM memiliki keterbatasan dalam menyelenggarakan pelatihan bagi anggota koperasi yang kini jumlahnya mencapai 3,61 juta orang. Belum lagi jika ditambah pelaku UMKM yang berjumlah hampir 12 juta orang. Membutuhkan waktu yang lama untuk menjangkau semuanya lebih lagi dimasa pandemic seperti saat ini (Dinas et al., 2019).

Beberapa aspek sumber daya manusia yang meliputi pengetahuan keterampilan dan kemampuan, pada hakekatnya akan dapat tercipta apabila dilakukan program pendidikan dan pelatihan. Menurut Notoatmojdo (2009:16) Pendidikan dan Pelatihan merupakan upaya untuk mengembangkan kemampuan-kemampuan intelektual dan kepribadian manusia. Pelatihan mempunyai manfaat baik bagi koperasi maupun pengurus/anggota yang mengikuti pelatihan. Manfaat bagi koperasi, yaitu keuntungan dan produktifitas koperasi, meningkatkan pengetahuan tantang manajemen dan kemampuan pada semua tingkatan. Pengurus/anggota yang teerlatih akan dapat membantu dalam pemecahan masalah dan pengambilan keputusan disamping juga paham tentang kondisi dan tujuan koperasi. Sedang manfaat bagi pengurus/anggota yang mengikuti pelatihan adalah sebagai beriku ; meningkatkan percaya diri dan keinginan untuk maju, memudahkan memecahkan masalah yang timbul, meningkatkan tanggung jawab. Serta mampu bekerja dengan tenang dalam menghadapi stres tekanan, frustasi, dan konflik.

Dengan adanya pandemic covid - 19 yang menyebabkan disrupsi besar - besaran dari offline menuju online, maka pelatihan dengan metode tatap muka tidak bisa dilaksanakan. Padahal, Koperasi dan UKM juga mendapat efek dari pandemi dimana pelatihan dibutuhkan untuk bertahan dan mengembangkan usaha serta adaptasi dengan kondisi pandemi. Melihat masalah tersebut, maka UPT Pelatihan Koperasi dan UKM Provinsi Jawa Timur telah menemukan solusi pelaksanaan pelatihan berbasis teknologi informasi yang memberikan pelayanan pembelajaran gratis namun tetap dapat dipertanggungjawabkan kredibilitasnya yaitu e-learning SIJAWARA.

E-learning SIJAWARA merupakan sebuah e-learning hasil inovasi UPT Pelatihan Koperasi dan UKM Provinsi Jawa Timur, yang dapat digunakan sebagai sarana atau media dalam penyelenggaraan pelatihan yang memanfaatkan teknologi informasi atau biasa disebut E-Learning. E-learning SIJAWARA diharapkan memberikan perubahan pada pengelolaan manajemen yang lebih baik dengan pengurus koperasi yang memiliki kompetensi memadai.

E-Learning SIJAWARA yang menggunakan platform android dan berbasis web yang dapat diunduh di google playstore, sebagai media pelatihan jarak jauh (E-Learning) adalah merupakan jawaban sebagai salah satu alternatif dalam sistem penyelenggaraan pelatihan 
dimasa sekarang. (Pelatihan, 2021) Pelatihan menggunakan E-learning yang dipersepsikan bersifat learner centered dapat meningkatan kualitas pembelajaran dan materi ajar, kualitas aktivitas dan kemandirian peserta pelatihan, dan bisa menjadi lebih interaktif baik komunikasi antara instruktur dengan peserta pelatihan, maupun antar peserta pelatihan. Dan yang tidak kalah pentingnya Aplikasi SIJAWARA tidak hanya berbicara kulitas saja tapi juga kuantitas, karena penyajian e-learning dengan Aplikasi SIJAWARA berbasis web ini tidak memiliki batasan akses, inilah yang memungkinkan pelatihan bisa dilakukan lebih banyak peserta dan lebih banyak waktu.

Berkaitan dengan kompetensi yang harus dimiliki oleh pengurus koperasi, Webstre's Ninth New Collegiate Dictionary dalam Sri Lastanti (2005) yang dikutip (suparno, 2012) Kompetensi adalah keterampilan dari seorang ahli, dimana ahli didefinisikan sebagai seseorang yang memiliki tingkat keterampilan tertentu atau pengetahuan yang tinggi dalam subyek tertentu yang diperoleh dari pelatihan dan pengalaman. Peraturan Menteri Koperasi UKM RI Nomor 15/Per/M.UKM/IX/2015 pasal 13 ayat 5 tentang usaha simpan pinjam bahwa pengelola koperasi wajib memiliki sertifikasi standar kompetensi yang dikeluarkan oleh lembaga sertifikasi profesi yang telah mendapat lisensi sesuai peraturan perundang-undangan. (Perkoperasian et al., 2021). Indikator penelitian ini adalah indikator yang terkandung dalam konsep kompetensi Gordon dalam Sutrisno, (2012: 204) yaitu : Pengetahuan (knowledge), Pemahaman (understanding), Nilai (value), Kemampuan (skill), Sikap (attitude), Minat (interest).

Banyak faktor, indikator, maupun aspek yang dapat mempengaruhi Kompetensi Pengurus koperasi antara lain, pengurus koperasi harus mau mengembangkan diri melalui pelatihanpelatihan koperasi. (Setyorini, 2007) menyatakan, agar pengurus koperasi dapat memiliki kompetensi baik dan meningkat, pengurus koperasi harus mengikuti pelatihan secara periodik. Karena pada hakekatnya pelatihan adalah merupakan metode yang dipergunakan untuk meningkatkan kompetensi pengurus koperasi yang merupakan sumber daya manusia suatu organisasi (Febrilia D. 2017). Semakin sering sumberdaya manusia tersebut mengikuti pelatihan, diharapkan terbentuk sumberdaya manusia yang berkualitas serta mempunyai kemampuan tinggi dan pada akhirnya berujung pada kompetensi sumberdaya manusia tersebut semakin meningkat.

Seperti diuraikan diatas, UPT Pelatihan Koperasi dan UKM Provinsi Jawa Timur telah memberikan inovasi pelatihan dengan memanfaatkan e-learning SIJAWARA, sehingga tidak hanya kualitas saja yang harus ditingkatkan, namun kuantitas pun bisa dikembangkan. Karena e-learning SIJAWARA tidak berbatas waktu maupun tempat. Sehingga tujuan penelitian ini adalah ; mendeskripsikan Pelatihan, E-Learning SIJAWARA, dan Kompetensi Pengurus Koperasi, menganalisis pengaruh Pelatihan terhadap Kompetensi Pengurus Koperasi, serta menganalisis pengaruh Pelatihan terhadap Kompetensi Pengurus Koperasi melalui E-Learning SIJAWARA.

\section{METODE PENELITIAN}

Penelitian ini merupakan penelitian penjelasan (explanatory research) dengan pendekatan statistik deskriptif dan statistik inferensial. Dengan populasi sejumlah 647 orang adalah peserta pelatihan yang pernah mengikuti pelatihan baik secara konvensional maupun pelatihan dengan pemanfaatan e-learning SIJAWARA penelitian dilakukan pada Koperasi di Jawa Timur yang merupakan binaan UPT Pelatihan Dinas Koperasi dan UKM Jawa Timur. Dan teknik pengambilan sampel menurut Taro Yamane dalam Bungin, B. (2010:105) didapat sampel sebesar 87 Responden. Teknik pengumpulan data menggunakan kuesioner dengan skala Likert 1 (satu) sampai 4 (empat).

Penelitian menggunakan Analisis jalur yang bertujuan untuk mengetahui besarnya pengaruh suatu variabel pelatihan terhadap variabel kompetensi pengurus koperasi baik pengaruh langsung maupun melalui variabel e-learning sijawara (tidak langsung). Langkah 
dalam melakukan analisis jalur membuat diagram jalur hubungan kausal dan persamaan struktur.

\begin{tabular}{|c|c|c|c|c|c|c|}
\hline \multicolumn{7}{|c|}{ Coefficients ${ }^{\mathrm{a}}$} \\
\hline \multirow{2}{*}{\multicolumn{2}{|c|}{ Model }} & \multicolumn{2}{|c|}{ Unstandardized Coefficients } & \multirow{2}{*}{$\begin{array}{c}\begin{array}{c}\text { Standardized } \\
\text { Coefficients }\end{array} \\
\text { Beta }\end{array}$} & \multirow[t]{2}{*}{$t$} & \multirow[t]{2}{*}{ Sig. } \\
\hline & & $\mathrm{B}$ & Std. Error & & & \\
\hline \multirow{2}{*}{1} & (Constant) & 11.430 & 1.334 & & 8.568 & .000 \\
\hline & PELATIHAN $(X)$ & .260 & .087 & 181 & 2.996 & .003 \\
\hline
\end{tabular}

Penelitian ini menggunakan alat analisis SPSS Versi 24 dalam model dan pengujian hipotesis. Analisis Regresi dilakukan untuk menguji dan menganalisis hubungan baik secara langsung atau tidak langsung atau sering disebut analisa jalur (Efendi \& Purnomo, 2012).

\section{HASIL DAN PEMBAHASAN}

Pada penelitian ini analisis data dilakukan dengan menggunakan teknik analisis jalur (path analysis), dimana analisis dilakukan untuk menjawab hipotesis yang diajukan dalam penelitian ini sesuai dengan pertanyaan penelitian menguji pengaruh langsung antara variabel independen terhadap variabel dependen maupun pengaruh tidak langsung melalui mediasi variabel intervening. Berdasarakan analisis menggunakan SPSS Versi 24 diperoleh hasil dari pengaruh Pelatihan (X) terhadap Kompetensi Pengurus Koperasi (Z) melalui E-Learning SIJAWARA (Y) adalah sebagai berikut:

\section{Hasil}

Nilai koefisien Pelatihan (X) dan E-Learning SIJAWARA (Y) terhadap Kompetensi Pengurus Koperasi (Z).

Nilai koefisien Pelatihan (X) terhadap E-Learning SIJAWARA (Y)

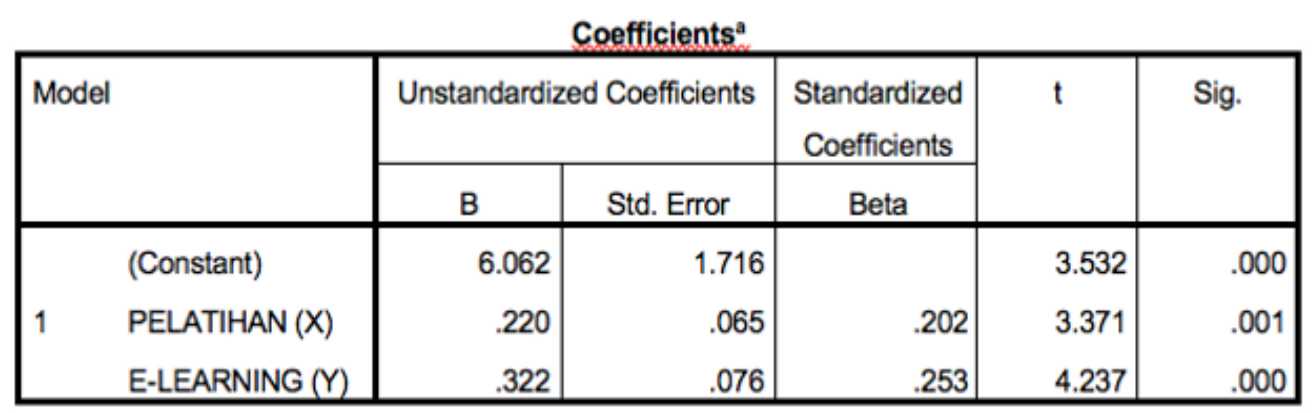

a. Dependent Variable: KOMPETENSI (Z)

Sumber: Hasil Analisis Data SPSS 24, 2021

- Pengaruh Pelatihan terhadap Kompetensi Pengurus Koperasi

Hasil dari pengujian yang tertera pada tabel di atas dapat diketahui bahwa nilai tstatistic Pelatihan terhadap Kompetensi Pengurus Koperasi adalah 3,371. Sedang t-tabel sebesar 1.98761, sehingga hasil pengujian tersebut menunjukkan bahwa nilai t- statistic (3,371)> t-tabel (1,98761). Dengan demikian dapat diartikan bahwa Pelatihan berpengaruh langsung terhadap Kompetensi Pengurus Koperasi. Hal ini juga didukung signifikansi $0,01<0,05$, yang berarti bahwa Pelatihan berpengaruh signifikan positif terhadap Kompetensi Pengurus Koperasi.

\section{- Pengaruh E-Learning SIJAWARA terhadap Kompetensi Pengurus Koperasi}

Hasil dari pengujian yang tertera pada tabel di atas dapat diketahui bahwa nilai tstatistik E-Learning Sijawara terhadap Kompetensi Pengurus Koperasi adalah 4,237. Sedang t-tabel sebesar 1.98761, sehingga hasil pengujian tersebut menunjukkan bahwa 
nilai t- statistik $(4,237)>$ t-tabel $(1,98761)$. Dengan demikian dapat diartikan bahwa $E$ Learning SIJAWARA berpengaruh langsung terhadap Kompetensi Pengurus Koperasi. Hal ini juga didukung signifikansi $0,00<0,05$, yang berarti bahwa E-Learning SIJAWARA berpengaruh signifikan positif terhadap Kompetensi Pengurus Koperasi.

- Pengaruh Pelatihan terhadap E-Learning SIJAWARA

Hasil dari pengujian yang tertera pada tabel di atas dapat diketahui bahwa nilai tstatistic Pelatihan terhadap E-Learning SIJAWARA adalah 2,996. Sedang t-tabel sebesar 1.98761, sehingga hasil pengujian tersebut menunjukkan bahwa nilai t- statistic $(2,996)>$ t-tabel (1,98761). Dengan demikian dapat diartikan bahwa Pelatihan berpengaruh langsung terhadap E-Learning SIJAWARA. Hal ini juga didukung signifikansi 0,03 < 0,05, yang berarti bahwa Pelatihan berpengaruh signifikan positif terhadap E-Learning SIJAWARA.

- Pengaruh Pelatihan (X) terhadap Kompetensi Pengurus Koperasi (Z) melaui E-Learning SIJAWARA (Y)

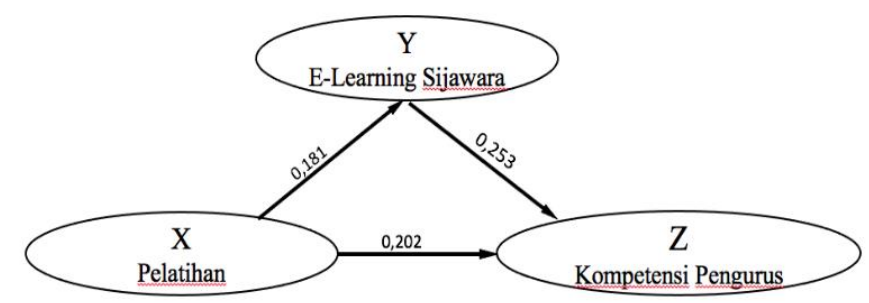

\section{Gambar 1. Bagan hubungan kausal dan persamaan struktur}

Untuk membuat diagram jalur hubungan kausal dan persamaan struktur dapat diambil dari table uji t hasil olah data SPSS 24.

Tabel 1. Koefisien Path

\begin{tabular}{|c|c|c|c|c|}
\hline Variabel & $\begin{array}{c}\text { Direct Effect } \\
\text { Coef. } \\
\text { (Standardized) }\end{array}$ & $\begin{array}{l}\text { Unstandardized } \\
\text { Coef. }\end{array}$ & Std Error & Sig $<0,05$ \\
\hline$X \rightarrow Z$ & 0,202 & 0,220 & 0,065 & Signifikan \\
\hline$X \rightarrow Y$ & 0,181 & 0,260 & 0,087 & Signifikan \\
\hline $\mathrm{Y} \rightarrow \mathrm{Z}$ & 0,253 & 0,322 & 0,076 & Signifikan \\
\hline $\begin{array}{l}\mathrm{X} \rightarrow \mathrm{Y} \rightarrow \mathrm{Z} \\
(\text { Indirect Effect) }\end{array}$ & $\begin{array}{l}0,181 \times 0,253= \\
0,045 .\end{array}$ & & & \multirow{2}{*}{$\begin{array}{l}\text { Sig (Sobel } \\
\text { Test) } \\
\text { Partial } \\
\text { Mediatif }\end{array}$} \\
\hline $\begin{array}{l}(\mathrm{X} \rightarrow \mathrm{Y} \rightarrow \mathrm{Z})+ \\
(\mathrm{X} \rightarrow \mathrm{Z}) \\
(\text { Total Effect })\end{array}$ & $\begin{array}{l}0,202+0,045= \\
0,247\end{array}$ & & & \\
\hline
\end{tabular}

Berdasarkan tabel koefisien path diatas, Pelatihan mempunyai pengaruh langsung signifikan terhadap Kompetensi Pengurus koperasi dengan nilai koefisien sebesar 0,202 dan Pelatihan mempunyai pengaruh langsung signifikan terhadap E-Learning SIJAWARA sebesar 0,181. Sedangkan E-Learning SIJAWARA mempunyai pengaruh langsung signifikan terhadap Kompetensi Pengurus koperasi dengan nilai koefisien sebesar 0,253. Selanjutnya nilai koefisien pengaruh tidak langsung Pelatihan terhadap Kompetensi Pengurus Koperasi melalui E-Learning SIJAWARA sebesar 0,045 dan nilai total sebesar 0,247. 
Untuk mengetahui nilai signifikansi (p-value) dari koefisien tidak langsung digunakan sobel test dengan cara memasukkan nilai Direct Effect Coef. (Standardized) dan Std Error secara online dalam www.quantspy.org/sobel/sobel/htm dan didapat data sebagai berikut ;

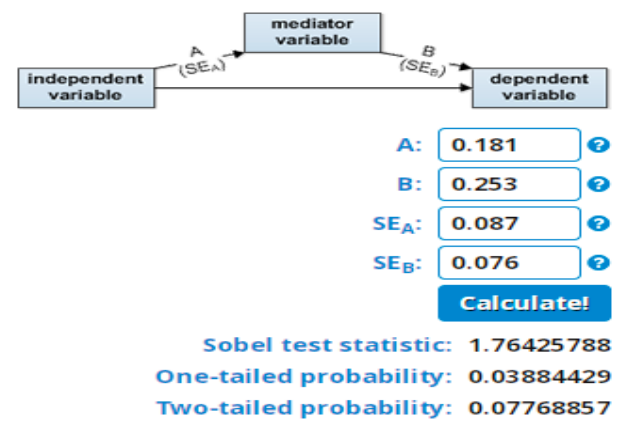

Data diatas mengartikan bahwa pengaruh Pelatihan terhadap Kompetensi Pengurus Koperasi mempunyai pengaruh langsung maupun tidak langsung melalui E-Learning SIJAWARA secara signifikan terhadap berdasar Sobel Test dengan p-value sebesar 0,03884429 .

\section{Pembahasan}

- Pengaruh Pelatihan dan E-Learning Sijawara terhadap Kompetensi Pengurus Koperasi

$$
\begin{aligned}
& Z=p Z X+p Z Y+\rho € 1 \\
& Z=0,220 X+0,332 Y+0,086 € 1
\end{aligned}
$$

Persamaan Regresi diatas dapat dilihat bahwa variabel pelatihan (X) mempunyai pengaruh yang signifikan terhadap variabel Kompetensi Pengurus Koperasi $(Z)$ hal ini, dapat diartikan bahwa secara langsung pelatihan berpengaruh positif dan signifikan terhadap kompetensi pengurus koperasi. Besaran pengaruh langsung pelatihan terhadap kompetensi pengurus koperasi adalah sebesar 0,220 atau 22,0\%. Dengan demikian, tinggi rendahnya kompetensi pengurus koperasi dipengaruhi oleh pelatihan sebesar 22,0\%, sedangkan sisanya $88,0 \%$ dijelaskan faktor lain di luar model dan semakin ditingkatkannya pelatihan maka Kompetensi Pengurus Koperasi akan menjadi lebih baik.

Hasil penelitian ini sesuai dengan penelitian sebelumnya yang yang dilakukan oleh Nabilah Rizkia Mokhtar dan Heru Susilo (2017); JP Agustin - 2019; Shanty Irma Idrus 2020 ; yang sama-sama menyatakan bahwa pelatihan berpengaruh positif terhadap Kompetensi Pengurus Koperasi.

Demikian juga halnya, dari Persamaan Regresi diatas dapat dilihat bahwa variabel E-Learning SIJAWARA Pengurus Koperasi (Z) hal ini, dapat diartikan bahwa secara langsung pelatihan berpengaruh positif dan signifikan terhadap kompetensi pengurus koperasi. Besaran pengaruh langsung E-Learning SIJAWARA terhadap kompetensi pengurus koperasi adalah sebesar 0,322 atau 32,2\%. Dengan demikian, tinggi rendahnya kompetensi pengurus koperasi dipengaruhi oleh E E-Learning SIJAWARA sebesar $32,2 \%$, sedangkan sisanya $67,8 \%$ dijelaskan faktor lain di luar model dan semakin ditingkatkannya pemanfaatan E-Learning SIJAWARA maka Kompetensi Pengurus Koperasi akan menjadi lebih baik. Hasil penelitian ini sesuai dengan penelitian sebelumnya yang yang dilakukan oleh Priyo Sidik Sasongko (2019), dan Novia Elga (2019) yang menyatakan bahwa E-Learning. berpengaruh positif terhadap Kompetensi Pengurus Koperasi.

- Pengaruh Pelatihan terhadap E-Learning Sijawara

$$
\begin{aligned}
& Y=p Y X+\rho € 2 \\
& Y=0,260 X+0,033 € 2
\end{aligned}
$$


Persamaan Regresi diatas dapat dilihat bahwa variabel pelatihan (X) mempunyai pengaruh yang signifikan terhadap variabel E-Learning SIJAWARA (Y) hal ini, dapat diartikan bahwa secara langsung pelatihan berpengaruh positif dan signifikan terhadap $E$ Learning SIJAWARA. Besaran pengaruh langsung pelatihan terhadap E-Learning SIJAWARA adalah sebesar 0,260 atau 26,0\%. Dengan demikian, tinggi rendahnya $E$ Learning SIJAWARA dipengaruhi oleh pelatihan sebesar $26,0 \%$, sedangkan sisanya $74,0 \%$ dijelaskan faktor lain di luar model dan semakin ditingkatkannya pelatihan maka E-Learning SIJAWARA akan menjadi lebih baik. Hasil penelitian ini sesuai dengan penelitian sebelumnya yang yang dilakukan oleh Hardiyan Indah (2018) menyatakan bahwa pelatihan mempunyai pengaruh yang signifikan terhadap E-Learning.

- Pengaruh Pelatihan terhadap Kompetensi Pengurus Koperasi melaui E-Learning Sijawara. Tabel Koefisien Path

\begin{tabular}{|c|c|c|c|c|}
\hline Variabel & $\begin{array}{l}\text { Direct Effect } \\
\text { Coef. } \\
\text { (Standardized) }\end{array}$ & $\begin{array}{l}\text { Unstandardized } \\
\text { Coef. }\end{array}$ & Std Error & Sig $<0,05$ \\
\hline$X \rightarrow Z$ & 0,202 & 0,220 & 0,065 & Signifikan \\
\hline $\mathrm{X} \rightarrow \mathrm{Y}$ & 0,181 & 0,260 & 0,087 & Signifikan \\
\hline $\mathrm{Y} \rightarrow \mathrm{Z}$ & 0,253 & 0,322 & 0,076 & Signifikan \\
\hline $\begin{array}{l}\mathrm{X} \rightarrow \mathrm{Y} \rightarrow \mathrm{Z} \\
(\text { Indirect Effect) }\end{array}$ & $\begin{array}{l}0,181 \times 0,253= \\
0,045 .\end{array}$ & & & \multirow{2}{*}{$\begin{array}{l}\text { Sig (Sobel } \\
\text { Test) } \\
\text { Partial } \\
\text { Mediatif }\end{array}$} \\
\hline $\begin{array}{l}(\mathrm{X} \rightarrow \mathrm{Y} \rightarrow \mathrm{Z})+ \\
(\mathrm{X} \rightarrow \mathrm{Z}) \\
(\text { Total Effect })\end{array}$ & $\begin{array}{l}0,202+0,045= \\
0,247\end{array}$ & & & \\
\hline
\end{tabular}

Dari pengolahan data yang telah dianalisis maka terdapat pengaruh tidak langsung pada Pelatihan terhadap Kompetensi Pengurus Koperasi melalui E-Learning SIJAWARA. Seperti hasil statistik melalui regresi dari tabel coefficient sub structural dapat diambil nilai signifikan dari variabel Pelatihan terhadap E-Learning SIJAWARA yaitu sebesar 0,001 $(<0,05)$ dan nilai signifikan variabel E-Learning SIJAWARA sebesar $0,000(<0,05)$ dapat diartikan bahwa bahwa terdapat pengaruh secara tidak langsung dari Pelatihan terhadap Kompetensi Pengurus Koperasi melalui E-Learning SIJAWARA.

Pada table path dapat dilihat bahwa pengaruh langsung Pelatihan terhadap Kompetensi Pengurus Koperasi dengan nilai koefisien (direct effect value) sebesar 0,202 dan pengaruh tidak langsung Pelatihan terhadap Kompetensi Pengurus Koperasi melalui E-Learning SIJAWARA dengan nilai koefisien (indirect effect value) sebesar 0,045, maka dapat dikatakan bahwa hubungan yang sebenarnya adalah hubungan langsung. Namun secara keseluruhan E-Learning SIJAWARA memberi kontribusi besar, sehingga pengaruh Pelatihan terhadap Kompetensi Pengurus Koperasi melalui E-Learning SIJAWARA mempunyai nilai koefisien total (Total effect) sebesar 0,247.

Dari Sobel Test juga menunjukkan bahwa pengaruh Pelatihan terhadap Kompetensi Pengurus Koperasi melalui E-Learning SIJAWARA memiliki pengaruh positif signifikan secara partial mediatif. Artinya bahwa pengaruh Pelatihan terhadap Kompetensi Pengurus Koperasi bisa melalui mediasi melalui E-Learning SIJAWARA. Namun pengaruhnya akan lebih besar bila menggunakan mediasi E-Learning SIJAWARA. Hal ini didukung oleh peneliti terdahulu Kusumaningtyas (2020) dan Rahbini (2021) yang menyatakan bahwa e-learning dapat memediasi Pelatihan dan Pengembangan terhadap Kompetensi. 


\section{KESIMPULAN}

Dari hasil uji hipotesis maka diperoleh suatu kesimpulan bahwa Pelatihan berpengaruh signifikan terhadap E-Learning SIJAWARA dan E-Learning SIJAWARA berpengaruh signifikan terhadap Kompetensi Pengurus Koperasi, sehingga Pelatihan berpengaruh signifikan tidak langsung terhadap Kompetensi Pengurus Koperasi melalui E-Learning SIJAWARA.

Pelatihan berpengaruh terhadap Kompetensi Pengurus Koperasi melalui E-Learning SIJAWARA secara positif signifikan secara partial mediatif. Artinya bahwa pengaruh Pelatihan terhadap Kompetensi Pengurus Koperasi bisa melalui mediasi melalui E-Learning SIJAWARA. Namun pengaruhnya akan lebih besar bila menggunakan mediasi E-Learning SIJAWARA. Sehingga kedepannya pembelajaran dengan metode blended learning yaitu Pelatihan Tatap Muka digabung dengan Pelatihan menggunakan E-Learning SIJAWARA akan berpengaruh lebih besar pada kompetensi pengurus koperasi.

\section{DAFTAR PUSTAKA}

Asgar, A., \& Rahayu, S. (2014). PENGARUH SUHU PENYIMPANAN DAN WAKTU PENGKONDISIAN UNTUK MEMPERTAHANKAN KUALITAS KENTANG KULTIVAR MARGAHAYU [Effect of Storage Temperature and Time Reconditioning to Maintain Quality of Potato Cultivars Margahayu]. Berita Biologi 13(3), 283-293.

Bariqi, M. D. (2020). Pelatihan Dan Pengembangan Sumber Daya Manusia. Jurnal Studi Manajemen Dan Bisnis, 5(2), 64-69. https://doi.org/10.21107/jsmb.v5i2.6654

Bungin Burhan. (2010). Metodologi Penelitian Kualitatif. PT. Raja Grafindo Persada. Jakarta.

Efendi, M. M., \& Purnomo, J. D. T. (2012). Analisis Faktor Konfirmatori untuk Mengetahui Kesadaran Berlalu Lintas Pengendara Sepeda Motor di Surabaya Timur. Fakultas Matematika Dan Ilmu Pengetahuan Alam, Institut Teknologi Sepuluh Nopember (ITS), 1(1), D106-D111.

Indah Permatasari, Hardiyan. (2018). Pengaruh E-Learning Sebagai Media Pelatihan dan Pengembangan Terhadap Kinerja Karyawan BCA KCU Tangerang

JP Agustin. (2019). Analisis Pengaruh Pelatihan Terhadap Kompetensi. Pada Rumah Sakit Islam Unisma

Khairudin, K., Rahmi, E., Rahmidani, R., Rusdinal, R., \& Gistituati, N. (2019). Analisis Kebijakan Penggunaan E-Learning Di Universitas Negeri Padang. Jurnal Ilmu Sosial Dan Humaniora, 8(2), 97. https://doi.org/10.23887/jish-undiksha.v8i2.21375

Lipi, I. (2021). ABOUT SEARCH CURRENT ARCHIVES ANNOUNCEMENTS ONLINE SUBMISSIONS SITE MAP CONTACT FAKTOR-FAKTOR YANG MEMPENGARUHI KINERJA KOPERASI NELAYAN DALAM UPAYA PENINGKATAN Full Text: Refbacks. 1-2.

Nabilah Rizkia Mokhtar dan Heru Susilo (2017) dengan judul Pengaruh Pelatihan Terhadap Kompetensi (Penelitian tentang Pelatihan pada Calon Tenaga Kerja Indonesia di PT Tritama Bina Karya Malang)

Notoatmodjo, Soekidjo. (2009). Pengembangan Sumber Daya Manusia. Jakarta: Rineka Cipta

Novi Rukhvianti, Rosida, Moch. Ali Ramdhani. (2021). Pengaruh Pelatihan dan Pengembangan melalui e-learning Terhadap Kompetensi Karyawan di Perusahaan X. https://ejournal.rosma.ac.id/index.php/inotek/article/view/123

Peraturan Menteri Koperasi UKM RI Nomor 15/Per/M.UKM/IX/2015

Rahbini, M. Iqbal (2021) Analisis pengaruh motivasi terhadap prestasi belajar mahasiswa dengan penggunaan media e-learning sebagai variabel intervening: Studi kasus mahasiswa Ekonomi UIN Maulana Malik Ibrahim Malang. http://etheses.uinmalang.ac.id/27042/

Rizqiya, Novia Elga. (2019). Pengaruh e-learning terhadap kompetensi kognitif peserta didik di kelas X MIPA 1 MAN 1 Gresik (http://digilib.uinsby.ac.id/38333/). 
Sasongko, Priyo Sidik, Bahtiar, Nurdin, Suhartono, S. (2019). Pengembangan E-Learning untuk Meningkatkan Kompetensi Pedagogik Guru-Guru SMPIT Bina Amal dan SMP Muhammadiyah 2 Semarang

Shanty Irma Idrus.(2020). Pengaruh Pelatihan Dan Motivasi Terhadap Kompetensi Manajerial Pegawai Negeri Sipil Sekretariat Jenderal Dan Badan Keahlian Dewan Perwakilan Rakyat Republik Indonesia

Suparno. (2012). Pengertian Kompetensi Menurut Para Ahli, Jenis, Manfaat Lengkap. 27.

Sutrisno. (2012). Manajemen Keuangan Teori Konsep dan Aplikasi. Yogyakarta : Ekonisia 